\title{
Sociodemographic profiling and study of maternal and perinatal outcome in patients suffering from eclampsia
}

\section{Latika Duhan*, Smiti Nanda, Pushpa Dahiya, Sushila Chaudhary}

\begin{abstract}
Department of Obstetrics and Gynaecology, Pandit Bhagwat Dayal Sharma Post Graduate Institute of Medical
\end{abstract} Sciences, Rohtak, Haryana, India

Received: 26 March 2016

Accepted: 23 April 2016

*Correspondence:

Dr. Latika Duhan,

E-mail: latika.duhan@gmail.com

Copyright: () the author(s), publisher and licensee Medip Academy. This is an open-access article distributed under the terms of the Creative Commons Attribution Non-Commercial License, which permits unrestricted non-commercial use, distribution, and reproduction in any medium, provided the original work is properly cited.

\begin{abstract}
Background: Eclampsia is defined as the occurrence of convulsions, not caused by any coincidental neurological disease such as Epilepsy, in a woman whose condition also meets the criteria for preeclampsia. The incidence is about 1:1600 pregnancies. Eclampsia is an acute obstetric emergency and quick treatment and timely decision making is required to get the best maternal and fetal outcome. The aim and objectives of the study was to socio demographic profile of the patients admitted with eclampsia and maternal and perinatal outcome in patients with eclampsia.

Methods: It was a record based retrospective study. The hospital files of patients admitted for the treatment of eclampsia during Oct 2012 to Dec 2013 were retrieved and were extensively studied. The data was entered in Microsoft excel and data base was created, appropriate statistical tests were applied and results were studied.

Results: It was found that majority of patients (74\%) belonged to age group of 21-30 years, were un booked (96\%) and $65 \%$ belonged to rural areas. Sixty five percent $(65 \%)$ of patients were admitted at less than 37 weeks of the gestational age and $67 \%$ of patients were primigravida. Majority of them had history of being normotensive. Majority of patients $(62 \%)$ were delivered by Caesarean section. Maternal mortality was found in six percent of the patients. Conclusions: Eclampsia is a frightening complication of pregnancy. It is life threatening to mother and fetus, however early treatment and delivery improves maternal and perinatal outcome.
\end{abstract}

Keywords: Eclampsia, Caesarean section, Maternal outcome, Perinatal outcome

\section{INTRODUCTION}

Preeclampsia that is complicated with generalized tonicclonic convulsions is termed eclampsia. Eclampsia is associated with devastating maternal and fetal complications. Eclampsia continues to be a major problem worldwide, particularly in developing countries. However in developed countries due to improved antenatal and intrapartum care the incidence of eclampsia has declined significantly. ${ }^{1,2}$ In few studies, it has been established that the good antenatal care can prevent the occurrence of eclampsia in majority of the cases. ${ }^{2-4}$ In India the incidence of eclampsia has been quoted as $1.56 \% .^{5}$ Majority of the cases of eclampsia are the patients who have not received proper medical attention during their antenatal period. ${ }^{6}$ Morbidity from eclampsia is associated with acute renal failure, pulmonary edema, cardiopulmonary arrest, and aspiration. ${ }^{2,7}$ Perinatal mortality has been as high as $59 / 1000$ [8] to $214 / 1000$ and morbidity as high as $56 \% .^{9,10}$ The causes of perinatal death are chronic placental insufficiency, preterm delivery, and placental abruption. ${ }^{11-15}$ Eclampsia is an acute obstetric emergency and swift treatment and prompt decision making is required to get the best maternal and fetal outcome.

Therefore a study was planned in the department of Obstetrics and Gynaecology at Post Graduate Institute of Medical Sciences, Rohtak to study the socio demographic profile of patients with eclampsia and to categorize the maternal and perinatal outcomes of eclamptic patients treated in our hospital. 


\section{METHODS}

It was a descriptive study carried out in the department of Obstetrics \& Gynecology of a leading tertiary care, academic and referral institute of Haryana. It was a retrospective study and the case sheets of the eclamptic patients admitted during the period of October 2012December 2013 were retrieved and were extensively analysed for studying the socio demographic profile of these patients viz. age, marital status, residence etc. and the factors associated with the eclamptic patients e.g. gestational age at the time of admission, ante partum Blood pressure etc. were recorded from the case sheets. Further, the various perinatal and maternal outcomes e.g. Still birth/ IUD, maternal complications during the delivery etc. were also extensively studied. The case sheets which were not retrieved from the Medical record department due to various reasons e.g. Non-deposition by the resident doctor, issuing for the court purpose etc. were excluded from the study.

\section{Data analysis}

The data was entered into the excel sheet and the data base was created. The data was analysed and various tables were prepared.

\section{Ethical justification}

No ethical issues are involved in this study as it was a record based retrospective study. There was no human or animal experimentation involved in this study. The confidentiality of the patient data was properly maintained and their identity was not revealed.

\section{RESULTS}

Table 1: Sociodemographic profiling of study population.

\begin{tabular}{|llll|}
\hline Variable & $\begin{array}{l}\text { Total No } \\
(\mathbf{N}) \text { and } \\
\text { Percentage }\end{array}$ & Variable & $\begin{array}{l}\text { Total No } \\
(\mathbf{N}) \text { and } \\
\text { Percentage }\end{array}$ \\
\hline $\begin{array}{l}\text { Age } \\
\text { (Years) }\end{array}$ & $\begin{array}{l}\text { Marital } \\
\text { status }\end{array}$ & & \\
\hline$<21$ years & $24(22 \%)$ & Single & - \\
\hline 21-30 years & $81(74 \%)$ & Married & $109(100 \%)$ \\
\hline$>30$ years & $4(4 \%)$ & Residence & \\
\hline Parity & Urban & $32(29 \%)$ & \\
\hline Primipara & $73(67 \%)$ & Rural & $71(65 \%)$ \\
\hline Multipara & $36(33 \%)$ & Not Known & $06(6 \%)$ \\
\hline
\end{tabular}

It was a retrospective study which included detailed analysis of record files of patients from October 2012 to December 2013. It was found that out of total patients, $74 \%$ belonged to age group of 21-30 years, $22 \%$ were $<21$ years and only $4 \%$ were $>30$ years of age. All patients were married. It was seen that $67 \%$ of the patients were primiparous and $33 \%$ were multiparous females. Majority (65\%) of them were from rural background, rest (29\%) were from cities (Table 1). It was noted that majority of the patients $(96 \%)$ were unbooked and only $4 \%$ of patients were booked at our hospital (Table 2). $65 \%$ of patients had their period of gestation as $<37$ weeks and $34 \%$ of patients were of $>37$ weeks period of gestation (Table 2). Period of gestation was undetermined in $1 \%$ patients. When urine albumin was analysed, it was found that $29 \%$ of patients had urine albumin as $2+$, approximately $28 \%$ of patient's had urine albumin as $4+$, around $20 \%$ of patients' urine albumin was $3+$ and in the remaining patients the urine albumin was $1+$. There was no albuminuria in $5 \%$ of patients (Table 2). $99 \%$ of patients were normotensive and only $1 \%$ patients gave history of being hypertensive before pregnancy. It was found that thirty patients $(28 \%)$ had time duration of less than six hours between onset of fits and delivery while seventy nine patients $(72 \%)$ delivered after six hours of onset of fits (Table 2). Out of total admitted patients, $62 \%$ underwent emergency LSCS, $32 \%$ had normal vaginal delivery and assisted vaginal delivery was performed in $6 \%$ of patients (Table 2). In majority $(50 \%)$ of patients, indication of caesarean section was fetal distress, followed by unfavourable cervix (39\%) and other indications (11\%) (Table 2). Common complications encountered in patients were abruption placenta $(6 \%)$, followed by acute renal failure $(6 \%)$, pulmonary edema $(4 \%)$, stroke $(3 \%)$, DIC $(1 \%)$, HELLP Syndrome (2\%) and others (15\%) (Table 3).

Table 2: Character sketch of study population.

\begin{tabular}{|c|c|c|c|}
\hline Variable & $\begin{array}{l}\text { Total No } \\
\text { (N) and } \\
\%\end{array}$ & Variable & $\begin{array}{l}\text { Total No }(\mathbf{N}) \text { and } \\
\%\end{array}$ \\
\hline \multicolumn{2}{|c|}{ Booking status } & \multicolumn{2}{|c|}{ Antenatal blood pressure } \\
\hline Booked & $4(4 \%)$ & Hypertension & $01(1 \%)$ \\
\hline $\begin{array}{l}\text { Un- } \\
\text { booked }\end{array}$ & $\begin{array}{l}105 \\
(96 \%)\end{array}$ & Normotensive & $108(99 \%)$ \\
\hline \multicolumn{2}{|c|}{$\begin{array}{l}\text { Gestational age at } \\
\text { the time of } \\
\text { admission }\end{array}$} & \multicolumn{2}{|c|}{$\begin{array}{l}\text { Time duration between onset of } \\
\text { fits and delivery }\end{array}$} \\
\hline $\begin{array}{l}<37 \\
\text { weeks }\end{array}$ & $71(65 \%)$ & $<6 \mathrm{hrs}$ & $30(28 \%)$ \\
\hline $\begin{array}{l}>37 \\
\text { weeks }\end{array}$ & $37(34 \%)$ & $>6 \mathrm{hrs}$ & $79(72 \%)$ \\
\hline $\begin{array}{l}\text { Not } \\
\text { known }\end{array}$ & $1(1 \%)$ & \multicolumn{2}{|c|}{ Mode of delivery } \\
\hline Proteinuria & & C-Section & $68(62 \%)$ \\
\hline 0 & $5(5 \%)$ & Normal & $35(32 \%)$ \\
\hline $1+$ & $\begin{array}{l}19 \\
(17.43 \%)\end{array}$ & $\begin{array}{l}\text { Assisted } \\
\text { Delivery }\end{array}$ & $6(6 \%)$ \\
\hline $2+$ & $\begin{array}{l}32 \\
(29.35 \%)\end{array}$ & \multicolumn{2}{|c|}{ Reasons for the cesarean section } \\
\hline $3+$ & $\begin{array}{l}21 \\
(19.26 \%)\end{array}$ & $\begin{array}{l}\text { Unfavourable } \\
\text { cervix }\end{array}$ & $42(39 \%)$ \\
\hline $4+$ & $\begin{array}{l}31 \\
(28.44 \%)\end{array}$ & $\begin{array}{l}\text { Foetal } \\
\text { distress }\end{array}$ & $55(50 \%)$ \\
\hline $\begin{array}{l}\text { Not } \\
\text { known }\end{array}$ & $1(1 \%)$ & Others & $1211 \%)$ \\
\hline
\end{tabular}


It was found that $94 \%$ patients were alive and $6 \%$ died due to various complications (Table 4). $96 \%$ patients delivered single baby and $4 \%$ patients had twin delivery. In 56\% new borns, Apgar score was $>7$, followed by $43 \%$ new borns who had Apgar score as $<7$ at 5 minutes. $65 \%$ of babies weighed normal at birth followed by $35 \%$ who had low birth weight. $82 \%$ patients delivered live baby, in $14 \%$ of patients outcome was IUD followed by early neonatal death in $4 \%$ of patients (Table 4 ).

Table 3: Maternal complications.

\begin{tabular}{|c|c|c|c|}
\hline Variable & $\begin{array}{l}\text { No. of } \\
\text { patients }\end{array}$ & Variable & $\begin{array}{l}\text { No. of } \\
\text { patients }\end{array}$ \\
\hline DIC & $1(1 \%)$ & $\begin{array}{l}\text { Abruptio } \\
\text { placenta }\end{array}$ & $6(6 \%)$ \\
\hline $\begin{array}{l}\text { Pulmona } \\
\text { ry edema }\end{array}$ & $4(4 \%)$ & $\begin{array}{l}\text { Acute renal } \\
\text { failure (ARF) }\end{array}$ & $7(6 \%)$ \\
\hline $\begin{array}{l}\text { HELLP } \\
\text { Syndrome }\end{array}$ & $2(2 \%)$ & Others & $17(15 \%)$ \\
\hline Stroke & $3(3 \%)$ & $\begin{array}{l}\text { No } \\
\text { complication }\end{array}$ & $69(63 \%)$ \\
\hline
\end{tabular}

Table 4: Maternal and perinatal outcome.

\begin{tabular}{|ll|}
\hline Variable & Total number \\
\hline Alive & $102(94 \%)$ \\
\hline Dead & $7(6 \%)$ \\
\hline Delivery outcome & \\
\hline Single & $90(96 \%)$ \\
\hline Twins & $4(4 \%)$ \\
\hline APGAR score at 05 Mins & \\
\hline Less than 7 & $40(43 \%)$ \\
\hline$>7$ & $53(56 \%)$ \\
\hline Not Known & $01(1 \%)$ \\
\hline Birth weight & \\
\hline Low birth weight & $33(35 \%)$ \\
\hline Normal birth weight & $61(65 \%)$ \\
\hline Perinatal outcome & \\
\hline Still birth/IUD & $15(14 \%)$ \\
\hline Early neonatal death & $4(4 \%)$ \\
\hline Alive & $90(82 \%)$ \\
\hline
\end{tabular}

\section{DISCUSSION}

Eclampsia is an obstetric emergency with significant maternal and fetal morbidity and mortality. Incidence of eclampsia has decreased significantly in developed countries but it is still very common in developing countries due to various reasons like lack of antenatal care, limited resources and settings etc. In our study, careful detailed analysis of record files revealed that incidence of eclampsia was more common (74\%) in young patients (21-30 years age group) and majority of them (67\%) were primiparous. This is in accordance with study of Acharya $G$ et al which showed that primigravidas were mostly affected (71.42\%) and eclampsia was more common in age group of 20-24 years
$(42.85 \%) .{ }^{16}$ Lack of antenatal care was found to be an important risk factor in various studies. ${ }^{17}$ In our study, $96 \%$ patients were unbooked and only $4 \%$ were booked in our hospital which was in correlation with above cited studies. During antenatal visits, routine screening methods help to identify potential eclamptic women but eclampsia may not always be predictable and preventable. In our study the incidence of eclampsia was more common $(65 \%)$ in patients with $<37$ weeks period of gestation. This is in correlation with U.K based study by Douglas et al, where it was found that the incidence of eclampsia was highest in patients $(44 \%)$ with less than 37 weeks of gestation. ${ }^{18}$ It was also concluded in their study that women with eclampsia in their early gestation period had more morbidity than women with eclampsia in late gestation. In our present study, it was found that $28 \%$ of patients had albuminuria as $4+$ while $19 \%$ of patients had $3+$ albuminuria. In various studies, it was revealed that the perinatal deaths are more in patients with high albuminuria. ${ }^{19,20}$ In the current study thirty patients $(28 \%)$ had time duration of $<6$ hours between onset of fits and delivery. Early delivery has been shown to cause less perinatal mortality in other study. ${ }^{20}$ In the present study, it was observed that majority of patients (62\%) had cesarean section as their mode of delivery and the commonest indication for cesarean section was fetal distress $(50 \%)$ followed by unfavorable cervix $(39 \%)$. The commonest maternal complication encountered were Abruptio placenta (6\%) and ARF (6\%) followed by pulmonary edema $(4 \%)$. In our study maternal mortality rate was $6 \%$. It correlates well with study carried out in India which reported maternal mortality rate as $7-8 \% .^{21}$ Better perinatal outcome has been associated with cesarean section in various studies. ${ }^{22-24}$ In our study, $82 \%$ of patients had live baby followed by $4 \%$ patients who had early neonatal deaths, which was less than that reported in Patan Hospital (31.25\%). ${ }^{16}$ It was observed that the perinatal outcome was poor in babies with low birth weight.

\section{Funding: No funding sources Conflict of interest: None declared Ethical approval: Not required}

\section{REFERENCES}

1. Chhabra S, Kakani A. Maternal mortality due to eclamptic and non-eclamptic hypertensive disorders: a challenge. J Obstet Gynaecol. 2007;27(1):25-9.

2. Urassa DP, Carlstedt A, Nystrom L, Massawe SN, Lindmark G. Eclampsia in Dar es Salaam, Tanzania - incidence, outcome, and the role of antenatal care. Acta Obstet Gynecol Scand. 2006;85(5):571-8.

3. Obed S, Aniteye P. Pregnancy following eclampsia: a longitudinal study at Korle-BU teaching hospital. Ghana Medical Journal. 2007;20:139-43.

4. Urassa D, Carlstedt A, Nystrom L, Msamanga G. Management of hypertension in pregnancy as a quality indicator of antenatal care in rural Tanzania. Afr J Reproductive Health. 2003;7:69-76. 
5. Swain S, Ojha KN, Prakash A. Maternal and perinatal mortality due to eclampsia. Indian Pediatr. 1993;30(6):771-3.

6. Case-Control Study of Risk Factors for Complicated Eclampsia. Obstetrics and Gynecology. 1997;90(2).

7. Sibai BM. Eclampsia. VI. Maternal-perinatal outcome in 254 consecutive cases. Am J Obstet Gynecol. 1990;163(3):1049-54.

8. Knight M. Eclampsia in the United kingdom 2005. BJOG. 2007;114(9):1072-8.

9. Onuh SO, Aisien AO. Maternal and foetal outcome in eclamptic patients in Benin CITY, Nigeria. J Obstet Gynaecol. 2004;24(7):765-8.

10. Lee W, O' Connell CM, Basket TF. Maternal and perinatal outcomes of eclampsia: Nova Scotia, 19812000. J Obstet Gynecol Can. 2004;26(2):119-23.

11. Alan $H$, Nathan L, Murphy $T$, Laufer $N$. Hypertension in pregnancy. Current diagnosis and treatment in Obstetric and Gynaecology. 10 ed: McGraw-Hill 2007.

12. Cunningham F, Kenneth J, Bloom S, Hauth J, Larry C, Wenstrom K. Hypertensive disorders in pregnancy. Williams Obstetrics. 22 ed: McGraw-Hill 2007.

13. Barton JR, Sibai BM. Prediction and prevention of recurrent preeclampsia. Obstet Gynecol. 2008;112(2 Pt 1):359-72.

14. Sibai BM. Hypertensive disorders of pregnancy: the United States perspective. Curr Opin Obstet Gynecol. 2008;20(2):102-6.

15. Sibai BM, Stella CL. Diagnosis and management of atypical preeclampsia-eclampsia. Am J Obstet Gynecol. 2009;200(5):481 e1-7.
16. Acharya G, Schultz S. Eclampsia in Patan Hospital: A two year retrospective study. JNMA. 1991;29:2548.

17. Sharda Jain, Sadhana Nager and DeepikaMonga: Maternal mortality following Eclampsia a critical analysis of 693 cases in two teaching hospitals in Northern India. The Journal of Obst Gynae of India. 1988;38:256-60.

18. Douglas LA. Redman CWG: Eclampsia in the United Kingdom. British Medical Journal. 1994;309:1395-400.

19. Dhananjay BS, Dayananda G, Sendilkumaran D, Murthy N. A Study of factors Affecting Perinatal Mortality in Eclampsia. JPBS. 2009;22(2):2-5.

20. Alam IP, Akhter S. Perinatal Outcome of Eclampsia in Dhaka Medical College Hospital, Dhaka. Bangladesh J Obstet Gynaecol. 2008;23(1):20-4.

21. Arora R, Ganguli RP, Swain S, Oumachigai A, Rajaram P. Detrminants of maternal mortality in Eclampsia in India. Aust NZ J Ob Gyn. 1994;34:5:537.

22. Innocent O. George, Israel Jeremiah. Perinatal Outcome of Babies Delivered to Eclamptic Mothers: A Prospective Study from a Nigerian Tertiary Hospital. International Journal of Biomedical Science. 2009;5(4):390-4.

23. Onwuhafua PI, Oguntayo A. Perinatal mortality associated with eclampsia in Kaduna, Northern Nigeria. Niger J Med. 2006;15(4):397-400.

24. Kamilya G, Barracharrya SK, Mukherji J. Changing trends in the management of eclampsia from a teaching hospital. J Indian Medical Association. 2005;103(3):132, 134-35.

Cite this article as: Duhan L, Nanda S, Dahiya P, Chaudhary S. Sociodemographic profiling and study of maternal and perinatal outcome in patients suffering from eclampsia. Int J Reprod Contracept Obstet Gynecol 2016;5:1870-3. 